\title{
Gender Specific Brood Cells in the Solitary Bee Colletes halophilus (Hymenoptera; Colletidae)
}

\author{
Eveline F. Rooijakkers • Marinus J. Sommeijer
}

Revised: 13 February 2009 / Accepted: 24 June 2009 /

Published online: 23 July 2009

C The Author(s) 2009. This article is published with open access at Springerlink.com

\begin{abstract}
We studied the reproductive behaviour of the solitary bee Colletes halophilus based on the variation in cell size, larval food amount and larval sex in relation to the sexual size dimorphism in this bee. Brood cells with female larvae are larger and contain more larval food than cells with males. Occasionally males are reared in female-sized cells. We conclude that a female $C$. halophilus in principal anticipates the sex of her offspring at the moment brood cell construction is started. Additionally a female is able to 'change her mind' about the sex of her offspring during a single brood cell cycle. We present a model that can predict the sex of the larvae in an early stage of development.
\end{abstract}

Keywords Bee $\cdot$ Colletes halophilus $\cdot$ sexual dimorphism $\cdot$ cell size $\cdot$ larval food $\cdot$ nesting

\section{Introduction}

Colletes halophilus Verhoeff (Hymenoptera; Colletidae) is a short-tongued mining bee, which may nest in large aggregations (Westrich 1989). This bee belongs to the Colletes succinctus group, among others with $C$. succinctus and C. hederae. The taxonomic and evolutionary position of this and related species is still subject of study (Kuhlmann et al. 2007).

Colletes halophilus occurs in tidal areas with brackish water. The flight season in The Netherlands is from August up to mid October (Peeters et al. 1999). Aster tripolium and Sonchus arvensis are reported to be major food sources of $C$. halophilus (Westrich 1989). However, we recently found that the larval food nearly exclusively contains A. tripolium pollen (Sommeijer et al. 2009). All colletid species are solitary and most are soil-nesting (Michener 2000). According to O'Toole and

E. F. Rooijakkers $(\bowtie) \cdot$ M. J. Sommeijer

Behavioural Biology, Utrecht University, P.O. Box 80.086, 3508 TB Utrecht, The Netherlands e-mail: e_rooijakkers@yahoo.com 
Raw (1999) the nest of $C$. halophilus consists of several brood cells, with five or six cells in a completed nest. Brood cells are constructed following the strict sequence of: excavation, lining of cell wall, provisioning, oviposition and closure (Michener 1964).

A remarkable characteristic shared by all colletid bees is the material used to line the brood cells (Michener 2000). The female spreads the lining material, mostly Dufour's gland secretions consisting of polyesters (specifically laminesters), with the glossa onto the inner wall. Probably, added salivary-gland secretions cause polymerisation and solidification (Michener 2000). This results in a tough inner wall of the cell that is translucent and cellophane-like (Michener 1964).

Another feature is that, unlike most other solitary bees, the provisions of most colletid bees are liquid. This is a suspension of pollen in a liquid that consists probably of floral nectar and glandular secretion (Michener 2000; O'Toole and Raw 1999; Sommeijer et al. 2009). Instead of laying the egg directly on the food mass, Colletes females place the egg on the upper part of the cell wall where it hangs above the surface of the liquid food (Michener 2000).

In 1943 Verhoeff described C. halophilus as a separate species and reported that males are 11-12 $\mathrm{mm}$ long and females 12-14 $\mathrm{mm}$ long. While doing research on this bees foraging behaviour (Sommeijer et al. 2009) we noted a remarkable size variation in the brood cells and in the amount of larval food within. Since female $C$. halophilus are larger then males (Verhoeff 1943) we hypothesized that females are reared in larger cells with a greater amount of larval food. Our goal was to confirm this hypothesis and construct a model that can accurately predict the sex of the offspring using very simple parameters.

\section{Methods}

\section{Bees and Site}

Colletes halophilus occurs in a scattered pattern along the North Sea and Atlantic coastline from the Netherlands (Peeters et al. 1999) southwards to Brittany and Aquitaine (Genoud and Dittlo 2007; Vereecken pers. comm. 2007). It is further reported to occur in the southwestern region of the UK (Scott Roberts pers. comm. 2006). In the Netherlands C. halophilus occurs along the coast, particularly in and near tidal wetlands in the Scheldt delta and on some Friesian islands (Peeters et al. 1999). The present study was performed with material collected from the aggregation site in the nature reserve 'Het Verdronken Land van Saeftinghe' $(3,000 \mathrm{Ha})$. This aggregation of about $3 \mathrm{Ha}$ is one of the largest aggregation sites of C. halophilus in the Netherlands.

\section{Analytic Procedures}

A total of 90 brood cells were collected shortly after the flight season in 2005 (on 711-2005). To determine the size of the brood cells, height $(H)$ and diameter (D) were measured 2 days later (accuracy of $0.5 \mathrm{~mm}$ ). Until that time cells were kept in sand. Figure 1 illustrates how measurements were taken. 
Fig. 1 Illustration of Colletes halophilus brood cells, indicated are how height and diameter measurements were taken.

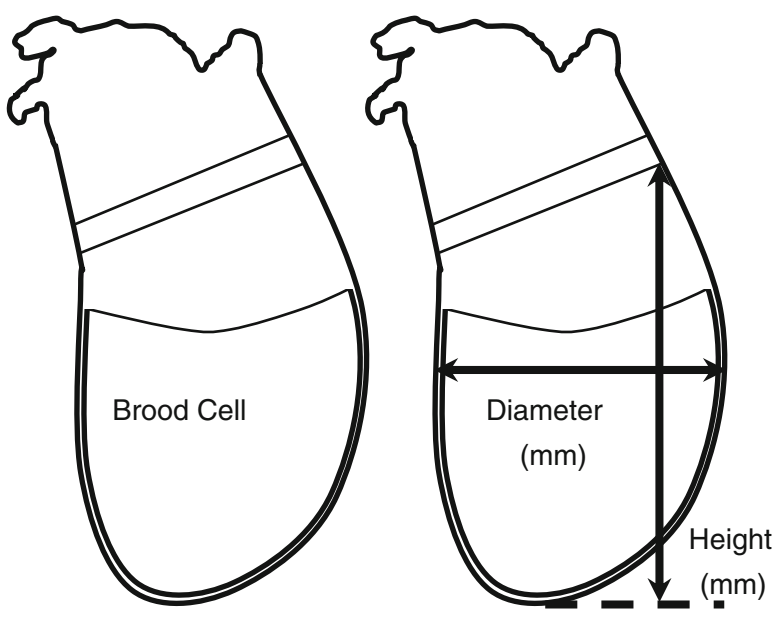

To assess the amount of larval food in the brood cells, the weight (W) of the cells was measured with an accuracy of $0.1 \mathrm{mg}$ (on 11-11-2005). The cells were weighed with larvae inside. Body weights of the still very small larvae were assumed to compensate for most of the food weight loss due to feeding. Weight loss due to respiration and growth were for the relevance of this study assumed still to be negligible at this early stage of development (Bosch and Vicens 2002).

The sex of the larvae was determined with a stereoscopic microscope, using a fixation and staining method described and illustrated by Duchateau and van Leeuwen (1990) for larvae of Bombus terrestris. This technique improves the visibility of the larval structures of the genital appendages. From the 90 cells the sex was determined for a total of 86 larvae: 67 males and 19 females.

\section{Statistical Analyses}

To investigate differences between cells of male and female larvae with respect to cell size and amount of food, Independent samples t-tests were used. To analyse the relationships between the parameters "diameter", "height" and "weight", Pearson correlation coefficients were conducted per sex.

Finally, logistic regression analysis was conducted to formulate a model by which the sex of the larvae can be predicted by one, or a combination, of the parameters "weight", "height" and "diameter". All analyses were performed using SPSS 10.0 for Macintosh.

\section{Results}

Brood Cell Size, Food Weight and Gender

Brood cells containing female larva were larger then cells containing males. They were both higher (female: Mean $(\mathrm{M})=13.5 \mathrm{~mm}, \mathrm{SD}=0.6$; male: $\mathrm{M}=12.0 \mathrm{~mm}, \mathrm{SD}=$ 0.8 ; Independent samples t-test: $t(84)=7.487, P<0.000,95 \%$ CI $[1.0 ; 1.8])$ and 
wider then cells with males (female: $\mathrm{M}=7.3 \mathrm{~mm}, \mathrm{SD}=0.4$; male: $\mathrm{M}=6.7 \mathrm{~mm}, \mathrm{SD}=$ 0.4 ; Independent samples t-test, $t(84)=5.285, P<0.000,95 \%$ CI $[0.4 ; 0.8]$ ) (See Fig. 2a and b). Also, cells with females were heavier then cells with males (female: $\mathrm{M}=266.8 \mathrm{mg}, \mathrm{SD}=35.6$; male: $\mathrm{M}=185.5 \mathrm{mg}, \mathrm{SD}=28.7$; independent samples t-test: $t(84)=10.316, P<0.000,95 \%$ CI $[65.6$; 97.0]) (Fig. 2c). Brood cells with female larvae were on average $81.3 \mathrm{mg}$ heavier (i.e. $43.8 \%$ ) then cells with males.

Cells containing female larvae showed a strong correlation between height and diameter (Fig. 3a; Pearson correlation: $r=0.621, n=19, P<0.005$ ), while cells containing males did not show this correlation (Fig. 3b; Pearson correlation: $r=$ $0.223, n=67, P<0.070$ ). For neither of the sexes a correlation was found between weight and diameter or weight and height (Pearson correlation: $|r|<0.210, P>0.089$ in all cases).

Fig. 2 Parameter distributions of Colletes halophilus brood cells with male (black) and female (white) larvae, (a) height ( $\mathrm{mm})$, (b) diameter ( $\mathrm{mm}$ ) and (c) weight (mg).
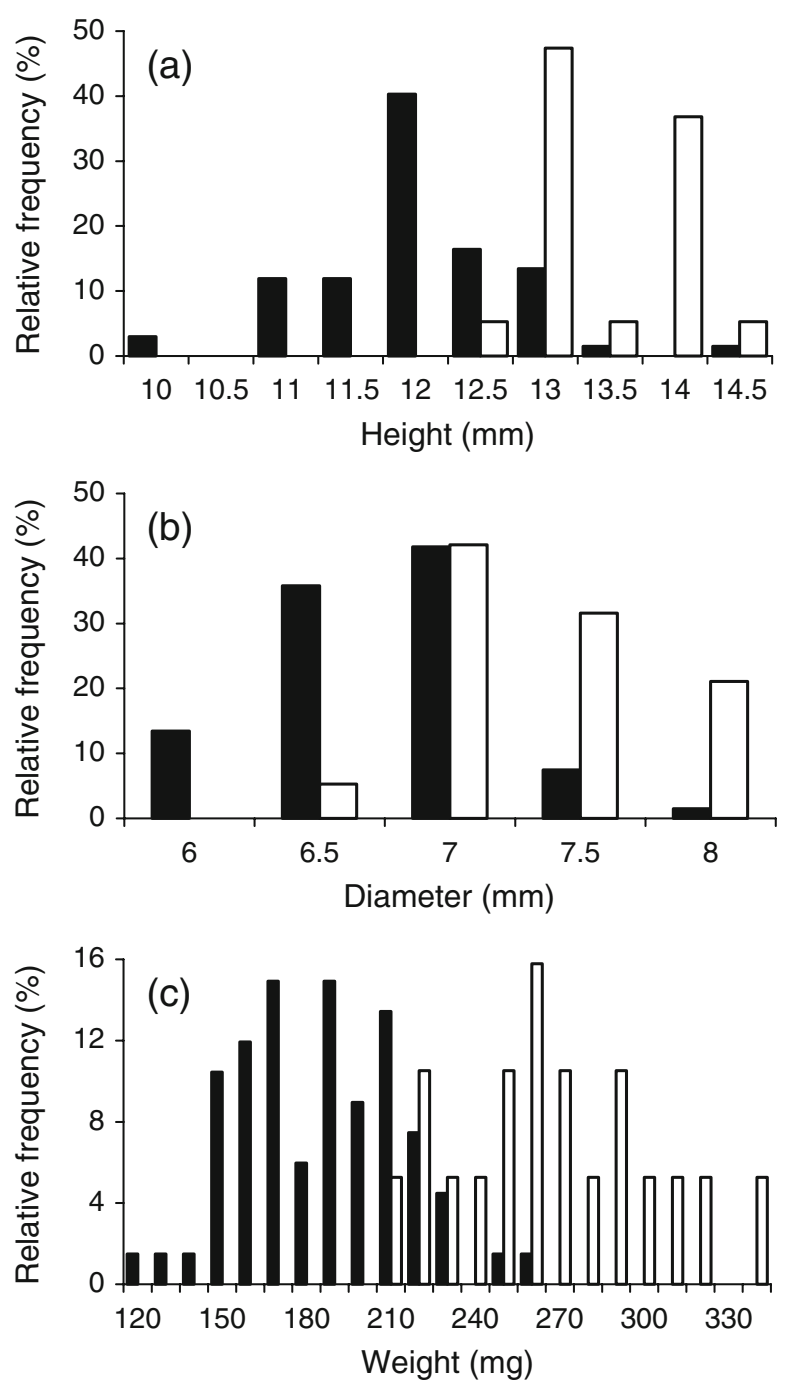
Fig. 3 Correlations between brood cell height $(\mathrm{mm})$ and diameter (mm) for cells containing (a) female and (b) male larvae of Colletes halophilus.
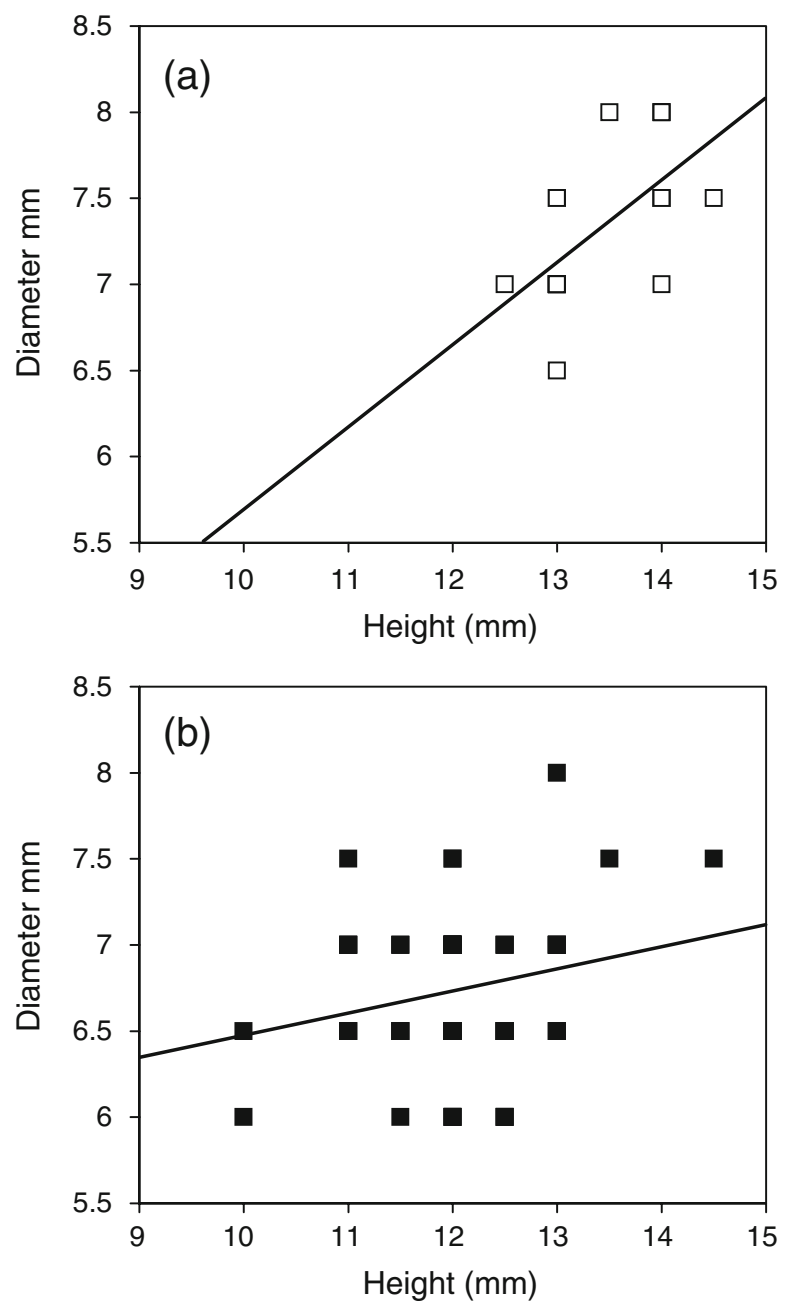

\section{Predicting Gender}

To establish a model for the prediction of the sex of the larvae, using a minimum of brood cell parameters, a logistic regression analysis was conducted on the parameters weight (W), height $(\mathrm{H})$ and diameter (D) (Table 1) using the data found in this study.

The weight $(\mathrm{W})$ of our brood cells alone predicted the gender of the larvae correctly in $93 \%$ of the times (males $97 \%$ correct, females $78,9 \%$ correct; two males and four females were incorrectly sexed). This resulted in the following equation $($ male $=1$, female $=0)$ :

$$
\ln (\mathrm{p} /(1-\mathrm{p}))=20.573-0.87 \mathrm{~W}
$$

With $\mathrm{p}$ the probability of finding a male, $\chi_{1}{ }^{2}(\mathrm{~W})=59,807 P=0.000$ (Table 1 ). 
Table 1 Results of Five Logistic Regression Analyses to Predict the Sex of the Larvae of Colletes halophilus Using Brood Cell Measurements $(\mathrm{M}=$ male, $\mathrm{F}=$ female). The First Three Analyses are on Each Parameter, Weight (W), Height (H) and Diameter (D), Separately. The Fourth and Fifth Analyses are on 'Weight and Height' and 'Weight and Diameter' Respectively. When Using Both Weight and Height, Gender Will be Predicted Correctly for 96.5\%. The Diameter of the Cell Will not Have Additional Value in Predicting When $\mathrm{H}$ is Already in the Model, i.e. for Model 2 Adding D Results in $P_{\mathrm{D}}=0.292$ and for Model 4 Adding D Results in $P_{\mathrm{D}}=0.527$

\begin{tabular}{|c|c|c|c|c|c|c|c|}
\hline \multirow{2}{*}{$\begin{array}{l}\text { Logistic } \\
\text { Regression } \\
\text { Analysis }\end{array}$} & \multirow{2}{*}{$\begin{array}{l}\text { Parameter } \\
\text { Combination }\end{array}$} & \multirow[t]{2}{*}{$x^{2}$} & \multirow[t]{2}{*}{ d.f. } & \multirow[t]{2}{*}{$P$} & \multicolumn{3}{|c|}{$\%$ Correctly predicted } \\
\hline & & & & & M & $\mathrm{F}$ & Total \\
\hline 1 & W & 59.807 & 1 & 0.000 & 97.0 & 78.9 & 93.0 \\
\hline 2 & $\mathrm{H}$ & 43.549 & 1 & 0.000 & 97.0 & 47.4 & 86.0 \\
\hline 3 & $\mathrm{D}$ & 23.687 & 1 & 0.000 & 91.0 & 52.6 & 82.6 \\
\hline \multirow[t]{2}{*}{4} & $\mathrm{~W}+\mathrm{H}$ & $33.754(\mathrm{~W})$ & 1 & $0.000(\mathrm{~W})$ & 98.5 & 89.5 & 96.5 \\
\hline & & $17.496(\mathrm{H})$ & 1 & $0.000(\mathrm{H})$ & & & \\
\hline \multirow[t]{2}{*}{5} & $\mathrm{~W}+\mathrm{D}$ & $42.470(\mathrm{~W})$ & 1 & $0.000(\mathrm{~W})$ & 97.0 & 78.9 & 93.0 \\
\hline & & 6.350 (D) & 1 & 0.012 (D) & & & \\
\hline
\end{tabular}

Height and weight combined resulted in the following equation $($ male $=1$, female $=0)$ (Fig. 4):

$$
\ln (\mathrm{p} /(1-\mathrm{p}))=76.108-0.102 \mathrm{~W}-4.082 \mathrm{H}
$$

With $\chi_{1}{ }^{2}(\mathrm{~W})=33.754, P=0.000$, and $\chi_{1}{ }^{2}(\mathrm{H})=17.496, P=0.000$ (Table 1). When both height and weight of our brood cells were used, the gender of the larva in those brood cell was predicted correct in $96.5 \%$ of the times (males $98,5 \%$ correct, females $89,5 \%$ correct). Only one male and two females were incorrectly sexed, which is illustrated in Fig. 4 where height and weight of our brood cells are combined with the corresponding equation.

Using height alone as a parameter in the logistic regression analysis resulted in the following equation $($ male $=1$, female $=0)$ :

$$
\ln (\mathrm{p} /(1-\mathrm{p}))=39.272-2.983 \mathrm{H}
$$

Fig. 4 Scatter plot of height (mm) and weight (mg) of brood cells containing male (black squares) and female (white triangles) larvae of Colletes halophilus. Equation line: In $(\mathrm{p} /(1-\mathrm{p}))=76.108-0.102$ $\mathrm{W}-4.082 \mathrm{~L}$, with $\mathrm{p}=$ chance of finding a male, $\mathrm{Chi}_{\mathrm{W}}{ }^{2}=33.754$, $P=0.000$, and $\mathrm{Chi}_{\mathrm{H}}{ }^{2}=17.496$, $P=0.000$, male $=1$, female $=0$.

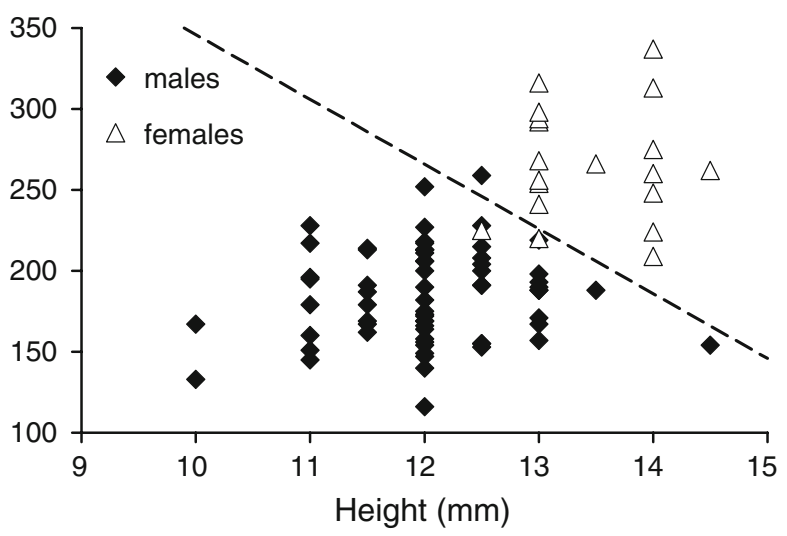


With $\chi_{1}{ }^{2}(\mathrm{H})=43,549 P=0.000$. When only the height of our brood cells was used, the gender of the larva in those brood cells was predicted correct $86 \%$ of the times (males 97\% correct, females 47,4\% correct). While only two out of 67 males were incorrectly sexed, no less then 10 out of 19 females were sexed incorrectly when only height was used.

Diameter alone is only slightly better at predicting a female (10 out of 19) but worse in predicting males (6 were wrongly sexed).

The adding of diameter (D) as a second parameter with height, or as a third parameter with weight and height, offers no additional value in the prediction of the gender of the larvae $\left(P_{\mathrm{D}}=0.292\right.$ and $P_{\mathrm{D}}=0.527$, respectively). Although adding diameter, as a second parameter, with weight is significant $\left(P_{\mathrm{D}}=0.012\right)$, this does not have an effect on the predicted outcome of $93 \%$ (see Table 1).

\section{Discussion}

The current study presents a model that can be used to predict the gender of a $C$. halophilus larva at an early stage of development, using the height and weight of the larva's cell. This model is based on our result showing that brood cells of $C$. halophilus that contain female larvae are larger and contain more larval food than cells containing male larvae.

With our model it is possible to differentiate between male and female brood cells simply by measuring the height and total weight of the cells. Although the total cell weight is only a rough estimate of the amount of larval food, this estimate was effective for our purpose. Since we did not correct for weight of the cell lining, weight of the young larva, and weight loss due to respiration, the presented equation to predict the gender can only be applied to larvae collected in an early stage of development.

The present study confirms our hypothesis that female $C$. halophilus are reared in larger cells with a greater amount of larval food. This also confirms a very early observation done by Van Lith (1937) in which he hypothesised that the size variation of brood cells in a population of $C$. succinctus (now identified as C. halophilus) could be related to the sexual size dimorphism in that bee.

These results are comparable to findings in other studies on solitary bees. For instance, Alcock (1999) found a correlation between brood pot height and weight of the pre-pupa in Amegilla dawsoni. This bee has strong size dimorphism between minor males and major males and females. Alcock (1999) also established, by counting provisioning trips, that the larger classes of bees received larger amounts of food. Bosch and Vicens (2002) used the position of a brood cell and larval food amount to determine gender in cells of the linearly nesting bee Osmia cornuta. Female cells of $O$. cornuta are usually positioned in the back of a nest.

Compared to male cells, $C$. halophilus female cells not only require more larval food, to be collected and transported, but also require more digging (making the cell wider) and a larger amount of glandular cell lining secretions. Female cells of $C$. halophilus are on average $43,83 \%$ heavier then male cells. We may assume that collecting the extra provision for a female descendant is the most cost increasing activity for a reproducing $C$. halophilus female. This implies that daughters are the 
more costly sex and rearing a son or a daughter has implications in terms of parental investment.

We can conclude that $C$. halophilus females in principal determine the sex of their offspring at the beginning of cell construction (i.e. is at the time of digging). Since females are reared only in larger cells with a larger amount of food, the strict sequence followed in brood cell construction, digging, lining, provisioning, oviposition and closure (Michener 1964) requires her to decide on the sex while digging. The haplodiploid sex determination mechanism, that allows, as in other Hymenoptera, for control over the sex of the egg at the moment of oviposition (Alcock 1999; Gerber and Klostermeyer 1970; Michener 1974; Winston 1987) makes this decision possible.

We found that a small number of males are reared in larger cells; depicted in Figs. $2 \mathrm{a}, \mathrm{b}$ and 4 . This suggests that a few brood cells originally built to house a female larva, ended up with a male larva. It is possible that some eggs in female sized cells were, by accident, not fertilized (e.g. the female was not fertilized or the sperm cell was not able to fertilize the egg) or that the female simply made an error during construction or oviposition. However, we have reason to believe there was some intent. This is supported by the absence of a correlation between size parameters height and diameter in cells with males; which indicates that males are not exclusively reared in smaller cells (i.e. size is more variable in cells with males). In contrast, we did find this correlation in cells containing females (Fig. 3a and b). Only rarely was a female reared in a male sized cell. Our model clearly indicates that the weight of a brood cell is an important factor when predicting sex. Figure 4 clearly illustrates that males in female sized cells all have a very low weight (bottom right). Apparently, when a cell is not adequately provisioned for a daughter, for example because the environment restricts her to collect enough brood cell provision (Tomkins et al. 2001), a female C. halophilus 'changes her mind' about the offspring sex in a "female" cell.

But what are the consequences of this mind changing? Isn't birth order important in solitary bees? And what are the implications?

In solitary bees, males are usually the first to emerge during the flight season (protandry), so that they are present when females emerge (Michener 2000; O'Toole and Raw 1999). Therefore, bees that construct linear nests in existing hollow cavities, for example Megachille rotundata (Peterson and Roitberg 2006) or $O$. cornuta (Bosch and Vicens 2005) need to consider birth order and first lay female eggs and afterwards male eggs in order for the males to have free exit. Unlike in linear nests, the nest architecture of $C$. halophilus is thus that cells do not block exits of other cells (O'Toole and Raw 1999). Consequently there is no need for the female to consider birth order of the two sexes for architectural reasons. A female $C$. halophilus may switch back and forth between producing males and females in one nest, depending on environmental circumstances. For a $C$. halophilus female to 'change her mind' and decide to produce a male, instead of the intended female, does not stipulate the subsequent offspring sex as it does in linearly nesting bees. This suggest that $C$. halophilus has a more flexible reproductive strategy then linearly nesting bees.

The current study presents a model that makes it possible to predict the sex of $C$. halophilus larvae in an early stage of development simply by using size and weight parameters of the brood cell. Females are reared in larger cells containing more 
provision then males. We conclude that females of $C$. halophilus in general anticipate the sex of their offspring at the onset of cell construction. In addition, they are able to make adjustments according to restricting environmental conditions without limiting the possibility to take full advantage of favourable environmental conditions.

Acknowledgements We are grateful to the Stichting Het Zeeuwse Landschap, and Chiel Jacobusse in particular, for supplying substantial support for this study. We thank Jos and Marianne Neve for their assistance at the nature reserve "Het Verdronken Land van Saeftinghe". Thanks also to Maria Schipper, Centre for Biostatistics, Utrecht University, for providing statistical assistance.

Open Access This article is distributed under the terms of the Creative Commons Attribution Noncommercial License which permits any noncommercial use, distribution, and reproduction in any medium, provided the original author(s) and source are credited.

\section{References}

Alcock J (1999) The nesting behavior of Dawson's burrowing bee, Amegilla dawsoni (Hymenoptera: Anthophorini), and the production of offspring of different sizes. J Insect Behav 12:363-384

Bosch J, Vicens N (2002) Body size as an estimator of production costs in a solitary bee. Ecol Entomol 27:129-137

Bosch J, Vicens N (2005) Sex allocation in the solitary bee Osmia cornuta: do females behave in agreement with Fisher's theory? Behav Ecol Sociobiol 59:124-132

Duchateau MJ, van Leeuwen P (1990) Early sex determination in larvae of Bombus terrestris. Insectes Sociaux 37:232-235

Genoud D, Dittlo F (2007) Contribution à la connaissance de Colletes halophilus Verhoeff (Hymenoptera, Colletidae) en France et confirmation de sa presence en Aquiteaine. Osmia 1:3-4

Gerber HS, Klostermeyer EC (1970) Sex control by bees: a voluntary act of egg fertilization during oviposition. Science 167:82-84

Kuhlmann M, Else GR, Dawson A, Quicke DLJ (2007) Molecular, biogeographical and phenological evidence for the existence of three western European sibling species in the Colletes succinctus group (Hymenoptera: Apidae). Organisms, Diversity \& Evolution 7:155-165

Van Lith JP (1937) Het zijdebijtje en haar nest. De levende natuur 41:305-308

Michener CD (1964) Evolution of the nests of bees. Am Zool 4:227-239

Michener CD (1974) The social behavior of the bees: A comparative study. Harvard University Press, Cambridge, 404 pp

Michener CD (2000) The bees of the world. The John Hopkins University press, USA

O'Toole C, Raw A (1999) Bees of the world. Blandford, London

Peeters TMJ, Raemakers IP, Smit J (1999) Voorlopige atlas van de Nederlandse bijen (Apidae). EISNederland, Leiden

Peterson JH, Roitberg BD (2006) Impacts of flight distance on sex ratio and resource allocation to offspring in the leafcutter bee, Megachile rotundata. Behav Ecol Sociobiol 59:589-596

Sommeijer MJ, Rooijakkers EF, Jacobusse C, Kerkvliet JB (2009) Larval food composition and food plants of the solitary bee Colletes halophilus (Hymenoptera: Colletidae). J Apic Res 48(3): in press

Tomkins JL, Simmons LW, Alcock J (2001) Brood-provisioning strategies in Dawson's burrowing bee, Amegilla dawsoni (Hymenoptera: Anthophorini). Behav Ecol Sociobiol 50:81-89

Verhoeff PMF (1943) Opmerkingen over Hymenoptera ÿculeate. Verslag van de Zes-en-zeventigste Wintervergadering der Nederlandse Entomologische Vereniging, March 6

Westrich P (1989) Die Wildbienen Baden-Württembergs. Spezieller Teil. Eugen Ulmer GmbH \& Co, Stuttgart, Germany

Winston ML (1987) The biology of the Honey bee. Harvard University Press, Cambridge, Massachusetts 